\title{
CORRESPONDENCE
}

\section{The supposed Cambrian at Fobbing, Essex, and the nature of some pre-Carboniferous in the northwestern part of the Kent Coalfield}

SIR - Recently the Geological Society has published two memoirs written by the lately lamented doyen of British palaeogeographers (Wills, 1973, 1978). The maps which they describe were compiled to provoke discussion concerning the nature and extent of the Palaeozoic rocks concealed below younger rocks in central and southern England. The purpose of this note is to strengthen the data on which the maps are based in two places; (1) by challenging the inference that Cambrian has yet been proved at Fobbing in south Essex (Wills, 1978, pl. 2, locality 13A, pp. 29, 34) and (2) by supplying faunal documentation for the inference of Upper Devonian at, or rather near, Chislet Colliery, Kent (Wills, 1978, pl. 1, Chislet $c_{3}$ ).

In the 1940s, I was one of those to whom G. M. Lees submitted for comment his MS speculative map of the sub-Mesozoic incrops in southeast England. I used that opportunity to re-examine in the Geological Survey collections, the fossil fragments which J. Pringle had recovered from very small shale chippings found at a depth of $1127-1153 \mathrm{ft}$ below Gault in a borehole at Fobbing (Pringle, 1925, p. 134). Cleaning these fragments of some matrix revealed that Pringle's identification of Acrotreta (and thus a Cambrian age) could not be substantiated because one fragment was of a palaeoniscid fish scale. This, numbered Pe 2200,1 submitted to Dr E. I. White who confirmed my palaeoniscid identification and possible Carboniferous assignment, and added that the age was unlikely to be older than Middle Devonian. I passed this information to Lees who made two brief references to it (Lees \& Taitt, 1944, p. 16; Lees, 1946, p. 6). On the earlier of Wills's maps (1973, pl. 1) the Palaeozoic rocks at Fobbing are classed as 'ORS(M. Dev.)' and the same stratal allocation is repeated on Plate 1 of the 1978 publication. The 1944 reassessment of the age of the Fobbing Palaeozoic contributed to the Geological Survey decision to commission the 1953 Canvey Island Borehole (Edmunds, 1954, p. 29).

Reference to Chislet, Kent, recalls that H. G. Dines (1933, pp. 29, 30) commented on the paucity of geological information concerning the age of strata encountered in some of the 1912-14 boreholes fringing the northern part of the Kent Coalfield. During visits to Chislet Colliery to examine cores from then current underground boreholes in the early 1940s, I enquired concerning the whereabouts of any cores from these 1912-14 boreholes and in November 1944, a colliery surveyor showed me a footpath in the colliery yard made up of cores which he told me came from the 1912 Chitty, Chislet Park and Rushbourne boreholes. Amongst these was a four or five-inch core length of grey-green calcareous shale, $5 \frac{1}{2}$ inches in diameter. In this I found a shelly mass composed mainly of large, undistorted Atrypa reticularis (Linnaeus) and occasional Cyrtospirifer cf. verneuillii (Murchison); one of the latter (CS 1729) recalled a similar shell from the Upper Devonian of Wolborough, Devon. Efforts to relate this core to such borers' records as were available proved inconclusive though I had a hunch that the core might have come from Rushbourne; other cores of different diameter yielded earlier Devonian fossils.

\section{References}

Dines, H. G. 1933. The sequence and structure of the Kent Coalfield. Summ. Progr. geol. Surv. G.B. for 1932, part 2, 15-43.

Edmunds, F. H. 1954. South-eastern District. Summ. Progr. geol. Surv. G.B. for 1953, part 2, p. 29.

Lees, G. M. 1946. The Exploration for Oil in Great Britain and its Economic Consequences. Abbot Memorial Lecture 1946. University of Nottingham publication.

Lees, G. M. \& Taitt, A. H. 1944. The geological results of the search for oilfields in Great Britain. Abstr. Proc. geol. Soc. Lond. no. 1408, 14-19.

Pringle, J. 1925. 2. Fobbing Boring. In 'Some recent borings in the London Basin', H. Dewey, J. Pringle and C. P. Chatwin. Summ. Progr. geol. Surv. G.B. for 1924, pp. 127-37.

Wills, L. J. 1973. A palaeogeological map of the Palaeozoic floor below the Permian and Mesozoic formations in England and Wales with inferred and speculative reconstructions of Palaeozoic outcrops in adjacent areas as in Permo-Triassic times. Mem. geol. Soc. Lond. 7, 1-23, 1 pl. 
Wills, L. J. 1978. Apalaeogeological map of the Lower Palaeozoic floor below the cover of Upper Devonian, Carboniferous and later formations with inferred and speculative reconstructions of Lower Palaeozoic and Precambrian outcrops in adjacent areas. Mem. geol. Soc. Lond. 8, 1-36, 2 pls.

35 Kent Avenue

JAMES STUBBLEFIELD

Ealing

London, W13 8BE

23rd February 1980 